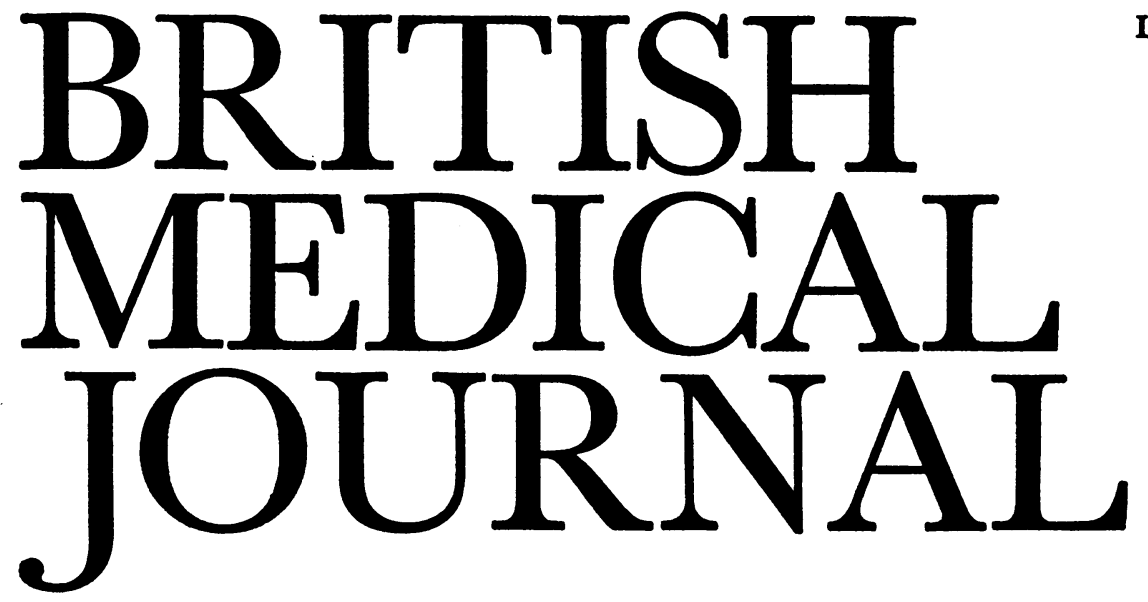

LONDON SATURDAY 11 NOVEMBER 1972

\title{
Freedom of the Medical Press
}

\author{
"It would be a sorry day if scientists were to be deterred from publishing their findings for \\ fear of libel actions."
}

Though the decision by Mr. S. L. Drummond-Jackson to discontinue his action against the B.M.A. and others announced on 31 October $^{1}$ will be widely welcomed, many doctors will regret that the Defendants had no direct opportunity to refute the serious accusations made against them. Nevertheless, most will see it as a victory for commonsense; others will wonder what has been achieved for such a vast outlay of time, money, and energy. Yet the fact is that the decision represents the vindication of an essential and traditional right: that of the medical press to publish in good faith articles and commentaries on matters of scientific importance to doctors-and through them to their patients-without fear of a libel writ. In this action this principle was challenged for the first time. Now that it has been reaffirmed all concerned in the search for scientific truth-authors, editors, and publishers-will have had one fear removed. In many ways it is fortunate that the action was brought against a journal able to resist such a challenge, because of its strong position and financial resources.

At the end of May 1969 the B.M.F. published an article from the Department of Anaesthesia at Birmingham University on physiological responses to intermittent methohexitone for conservative dentistry, ${ }^{2}$ and accompanied it by a leading article. ${ }^{3}$ In accordance with usual practice the anticle had been read carefully, both by several medical editors and by an expert outside assessor. The draft of the leading article was commissioned from another expert in the field, carefully edited in the customary way, and finally checked by the journal's legal adviser.

Five days after the original and the leading anticles appeared in the British Medical Fournal, the journal received a letter from Mr. Drummond-Jackson's solicitors alleging that the paper was gravely defamatory of him and that it and the editorial would have a serious effect on his general professional reputation. Among other things, the letter asked for a statement in the B.M.f. unreservedly withdrawing all imputations, an agreed statement in open court, and an undertaking not to publish any similar statements in future. In its reply the B.M.f. said that in accordance with normal practice in scientific controversy they would be prepared to consider for publication a letter explaining Mr. Drummond-
Jackson's point of view. At this stage the plaintiff issued a writ for libel, though letters to the Editor about the articles continued to appear in our correspondence columns.

In October of the same year the B.M.F. issued a summons for the action to be struck out. This was dismissed and the B.M.F. then appealed against the decision. Though the appeal was dismissed by two judges, the presiding judge, Lord Denning, said he would have allowed it. Part of his judgement bears repeating here, for it goes right to the heart of the problem. The Defendants, Lord Denning said, had "only exercised the right of lawful criticism. It would be a sorry day if scientists were to be deterred from publishing their findings for fear of libel actions. So long as they refrain from personal attacks, they should be free to criticize the systems and techniques of others. It is in the interests of truth itself. Were it otherwise, no scientific journal would be safe."

Subsequently, a further attempt was made to settle the action by submitting that the court was an inappropriate forum for the discussion of scientific researches, emphasizing the disproportionate expense involved, and offering the plaintiff the opportunity of stating his case in the B.M.f. Nevertheless, this was not accepted and the action began on 12 June. ${ }^{4}$ Though the plaintiff's case was said to be only half completed by Day 35, when he discontinued the action, the evolution of the proceedings fully justified the journal's initial standpoint: despite the skill of everybody concerned, a court of law is not the right place for scientific controversy. What is more, as the agreed statement on 31 October $^{1}$ pointed out, "the British Medical fournal has a right and duty to its readers and to the medical profession generally to publish articles such as that submitted to them by the individual Defendants and to comment on them."

One of the features common to all professions is the search for truth, which is as inherent in the doctor/patient relationship as in the confrontation between advocate and witness in cross-examination. A search for truth also underlies all scientific research, in which classically hypothesis is succeeded by experiment, result, and then new hypothesis. Argument among fellow workers is the fermentation that leads to truth, and truly effective argument needs com- 
munication which should be fettered only by the demands of good faith. Editors of scientific and medical journals must hold the ring. In doing so they must test articles by criteria of originality, scientific reliability, and professional ethics. They submit them to scrutiny by experts on whose integrity they rely. Before publication they negotiate with authors over important changes needed, and after publication allow free argument in the journal's correspondence columns.

All this is a heavy burden but the traditionally goodtempered hurly burly of medical and scientific argument testifies that this approach does result in freedom with responsibility. Fortunately, it is rare for anyone to challenge it-and certainly in a court of law. Though the recent libel case did not come to judgment, it is to be hoped that its result will remind those contemplating such an action of Milton's argument against censorship, 5 written over 300 years ago: "Where there is much desire to learn, there of necessity will be much arguing, much writing, many opinions; for opinion in good men is but knowledge in the making."

\footnotetext{
1 British Medical fournal, 1972, 4, 254.

2 Wise, C. C., Robinson, J. S., Heath, M. J., and Tomlin, P. J., British Medical fournal, 1969, 2, 540.

3 British Medical fournal, 1969, 2, 525.

- British Medical fournal, 1972, 2, 774; 3, 60, 122, 184, 245, 300, 360, and $423 ; 4,246,308$, and 372 .

5 Milton, J., Areopagitica. London, 1644.
}

\section{ABO Blood Groups and Abortion}

Shortly after the ABO blood groups were discovered attention was directed to the possibility of harmful effects when mother and fetus have different blood groups. As early as 1905 A. Dienst ${ }^{1}$ suggested that toxaemia of pregnancy might be due to the transfusion of $\mathrm{ABO}$-incompatible fetal blood into the mother. This was not substantiated, and the problem of $\mathrm{ABO}$ interaction between mother and fetus was largely overshadowed by the more dramatic effects of $\mathrm{Rh}$ incompatibility leading to $\mathrm{Rh}$ haemolytic disease.

Nevertheless, work has continued on ABO interactions, and particularly on $\mathrm{ABO}$ incompatibility in which the maternal and paternal blood groups are such that the father would be unable to donate blood to the mother. Thus, although the blood groups are different, an $\mathbf{A}$ mother and an $O$ father would be ABO-compatible, but an $\mathrm{O}$ mother and an $\mathrm{A}$ father would be defined as an ABO-incompatible mating. A further complication is that a father with blood group $\mathrm{A}$ may be homozygous $\mathrm{AA}$ or heterozygous $\mathrm{AO}$, and thus an ABO-incompatible mating in which the father is $A$ and the mother $O$ may produce a compatible $O$ or an incompatible A fetus.

ABO incompatibility between mother and fetus may lead to $\mathrm{ABO}$ haemolytic disease. This is much milder than $\mathbf{R h}$ haemolytic disease, and, though fatalities have been reported, P. L. Mollison ${ }^{2}$ noted that transfusion was required for only three of 14,000 newborn babies. It has, however, been shown that ABO incompatibility between mother and fetus may lead to loss of the fetus. L. Hirszfeld and $\mathrm{H}$. Zborowski ${ }^{3}$ noted a deficiency of group A offspring in matings in which the father was group $A$ and the mother group $O$, but the converse mating of an $A$ mother with an $O$ father produced the expected frequency of $\mathbf{A}$ offspring. J. A. H. Waterhouse and
L. Hogben ${ }^{4}$ analysed 453 families of $\mathrm{A}$ and $\mathrm{O}$ matings and found a $25 \%$ deficiency of A children when the mother was group $\mathrm{O}$. This deficiency of ABO-incompatible offspring has since been confirmed, ${ }^{5-7}$ and the effect could be due to a diminution in fertilizing capacity of ABO-incompatible sperms or to early loss of $\mathrm{ABO}$-incompatible fetuses.

The abortion rate is about $15 \%$ for all pregnancies, and it has come to be accepted as a natural "human" affliction. Though abortion probably does serve a physiological purpose in removing defective fetuses, other mechanisms certainly operate, and the magnitude of the clinical problem justifies investigation. C. McNeil and colleagues ${ }^{8}$ showed that $\mathrm{ABO}$ incompatibility was a cause of habitual abortion, and a recent study by $K$. Takano and J. R. Miller ${ }^{9}$ has added valuable information. They studied the ABO groups of mother and fetus in a series of abortions. This is a more powerful method of analysis than simply determining the ABO status of the parents, because, as noted above, an ABOincompatible mating does not necessarily produce an ABO incompatible fetus. These workers had available a large number of preserved fetuses from another research project. Using a mixed agglutination technique, ${ }^{10} 11$ they determined the blood groups of these fetuses from blood coagula obtained from the heart and great sinuses. (The mucopolysaccharide blood group antigens do not lose their specificity after exposure to formalin as a preservative.) The $\mathbf{A B O}$ groups were determined in 78 abortuses, and $35(44.7 \%)$ were incompatible, compared with a predicted 17 as calculated from the ABO frequency of the local population in British Columbia. This excess of incompatible abortuses is statistically significant and suggests that $\mathrm{ABO}$ incompatibility is a cause of abortion. This view is strengthened by the finding that developmental abnormalities capable of inducing abortion were found in $18.6 \%$ of the compatible abortuses compared with only $8.6 \%$ of the incompatible abortuses. Similar results have been reported by $\mathbf{H}$. Krieg and $\mathrm{K}$. Kasper ${ }^{12}$ in a smaller series.

It may be concluded that $\mathrm{ABO}$ incompatibility is a cause of abortion, and this raises several questions. How common is it? It cannot be a major cause of abortion, as the available data put the maximum incidence at about $40 \%$ of all abortions and the true incidence is probably lower. It may be of more importance in recurrent aborters than in women with isolated abortions. If ABO incompatibility is suspected as a cause of repeated abortion, can anything be done about it? Attempts to lower the level of circulating antibodies with immunosuppressive drugs would be contraindicated in pregnancy, but it has been possible to lower the titre of circulating antibodies in $\mathrm{Rh}$ haemolytic disease by intensive plasmapheresis, ${ }^{13}$ and this approach might be worth exploring. There is also evidence that $\mathrm{ABO}$ incompatibility is a cause of infertility. S. J. Behrman and colleagues ${ }^{14}$ studied a series of infertile matings in which all known causes of infertility had been excluded and found that $87.3 \%$ were ABO-incompatible as compared with an incompatibility rate of $38.6 \%$ in a series of fertile matings. ABO incompatibility between mother and fetus is clearly an important subject with therapeutic possibilities, and further developments in this field will be awaited with interest.

1 Dienst, A., Zentralblatt für Gynakologie, 1905, 29, 353.

2 Mollison, P. L., Blood Transfusion in Clinical Medicine, 4th edn. Oxford, Blackwell, 1967.

3 Hirszfeld, L., and Zborowski, H., Klinische Wochenschrift, 1925, 1, 1152.

- Waterhouse, J. A. H., and Hogben, L., British fournal of Social Medicine, 1947, 1, 1.

Matsunaga, E., Eugenics Quarterly, 1962, 9, 36.

- Cohen, B. H., American Fournal of Human Genetics, 1970/1971, 22, 412. 